\title{
PENELITIAN STRATEGI PENGUATAN KERJASAMA KEBIJAKAN PEMBANGUNAN PARIWISATA DI JAWA TENGAH (STUDI KASUS KSPN DIENG DAN SEKITARNYA)
}

\author{
RESEARCH STRATEGY STRENGTHENING TOURISM DEVELOPMENT POLICY IN \\ CENTRAL JAVA (CASE STUDY OF KSPN DIENG)
}

\author{
Tri Risandewi, Wiwin Widiastuti \\ Bappeda Prov. Jateng \\ Jl. Pemuda No. 127-133 Semarang \\ Email: reesha83@yahoo.com
}

Diterima: 21 Oktober 2019, Direvisi: 20 Desember 2019, Disetujui: 20 Januari 2020

\begin{abstract}
ABSTRAK
Kawasan pariwisata Dieng merupakan kawasan wisata potensial di Jawa Tengah baik sumber daya alam, dan budayanya, namun menyimpan potensi konflik yang rentan. Sebagai suatu kawasan wisata yang potensial, keunikan Dieng tidak hanya karena adanya objek wisata yang beraneka ragam dalam satu kawasan, namun juga merupakan sebuah kawasan wisata yang terbagi menjadi dua wilayah administratif, yaitu Kabupaten Banjarnegara dan Kabupaten Wonosobo. Pengelolaan Kawasan Wisata Dieng yang baik akan sulit dilakukan tanpa adanya kerjasama antar daerah. Tujuan penelitian ini adalah untuk: 1) mengidentifikasi kondisi kerjasama antar daerah dalam pengelolaan KSPN Dieng dan sekitarnya; 2) menganalisis faktor-faktor penghambat dan pendorong kerjasama antar daerah; dan 3) merumuskan strategi penguatan kerjasama kebijakan pembangunan pariwisata di KSPN Dieng. Metode yang digunakan dalam penelitian ini adalah deksriptif kualitatif dengan lokasi enelitian di KabupatenWonosobo, Banjarnegara, Batang dan Pekalongan. Adapun hasil penelitian yang diperoleh yaitu (1) kerjasama antar daerah dalam hal pengelolaan KSPN Dieng sudah ada sejak tahun 1974 hingga tahun 2012, namun kerjasama dilakukan secara parsial, yaitu antar 2 (dua) kabupaten atau kerjasama pemerintah provinsi dengan 1 (satu) kabupaten dalam sub sektor pariwisata tertentu; (2) faktor-faktor yang menghambat kerjasama antar daerah diantaranya tidak ada persamaan persepsi, lemahnya koordinasi antar sektor,belum adanya regulasi kerjasama antar stakeholder, sedangkan faktor pendorong: dukungan stakeholder dan dana, serta banyaknya event wisata bersama; (3) strategi penguatan yang perlu dilakukan yaitu tata kelola destinasi pariwisata yang terpadu dan bersinergi dengan membentuk kelembagaan khusus.
\end{abstract}

Kata Kunci: kerjasama periwisata antar daerah, KSPN Dieng

\begin{abstract}
Dieng tourism area is a potential tourism area in Central Java, both natural resources and culture, but saves the potential for conflict that is vulnerable. As a potential tourism area, Dieng's uniqueness is not only due to the diversity of tourist attractions in one region, but also is a tourist area which is divided into two administrative regions, namely Banjarnegara Regency and Wonosobo Regency. Good management of the Dieng Tourism Area will be difficult without cooperation between regions. The purpose of this study is to: 1) identify the conditions of cooperation between regions in the management of the KSPN Dieng, 2) analyze the inhibiting and driving factors of regional cooperation; and 3) formulate strategies to strengthen tourism
\end{abstract}


development policy cooperation in the KSPN Dieng. The method used in this research is descriptive qualitative research locations in Wonosobo Regency, Banjarnegara, Batang and Pekalongan. The research results obtained are (1) cooperation between regions in terms of management of the KSPN Dieng which has existed from 1974 to 2012, but the collaboration is carried out partially, namely between 2 (two) districts or cooperation between the provincial government and 1 (one) district in certain tourism sub sectors; (2) factors that hamper inter-regional cooperation including there is no common perception, weak inter-sectoral coordination, lack of cooperation regulations between stakeholders, while driving factors: stakeholder support and funds, as well as the number of joint tourism events; (3) strengthening strategies that need to be carried out, namely the management of tourism destinations that are integrated and synergized by forming special institutions.

Keywords: inter-regional tourism cooperation, KSPN Dieng

\section{PENDAHULUAN}

Pariwisata adalah agent of development atau katalisator pembangunan dilihat dari berbagai peranannya di dalam perekonomian. World Tourism Organization (WTO) menyatakan bahwa industri pariwisata diramalkan akan menjadi industri terbesar di dunia. Pariwisata merupakan salahsatu industri dengan pertumbuhan tercepat di dunia. World Tourism Organization menyatakan bahwa perkembangan industri pariwisata akan terus tumbuh mencapai $4,3 \%$ per tahun sampai tahun 2020 (Furi, 2012). Indeks daya saing pariwisata Indonesia naik 8 peringkat menjadi 42 dari posisi 50 besar dunia menurut data World Economic Forum (WEF) pada tahun 2017.

Pariwisata merupakan salahsatu sektor pembangunan yang saat ini sedang digalakkan oleh pemerintah. Pariwisata perlu terus didorong perkembangannya karena dengan meningkatnya destinasi dan investasi pariwisata di Indonesia akan meenjadi faktor kunci dalam pendapatan ekspor, penciptaan lapangan kerja, pengembangan usaha dan infrastruktur. Sektor pariwisata mempunyai peran yang sangat penting dalam pembangunan Indonesia khususnya sebagai penghasil devisa negara. Pada tahun 2010 devisa yang masuk dari sektor pariwisata mencapai US\$ 7,60 milyar dan meningkat menjadi US\$ 10 milyar lebih pada tahun
2014 (BPS, 2016). Sebagai penghasil devisa pada khususnya dan pendapatan negara dan masyarakat pada umumnya, karena sektor pariwisata mampu membuka perluasan kesempatan serta lapangan kerja dan mendorong kegiatan-kegiatan industri penunjang dan industri-industri sampingan lainnya. Kontribusi sektor priwisata terhadap PDB nasional selalu meningkat dari tahun 2010 sebesar Rp. 261,05 trilyun menjadi Rp. 461,36 trilyun pada tahun 2015 dan penyerapan tenaga kerja dari sektor pariwisata juga mengalami peningkatan dari 4 juta orang pada tahun 2010 menjadi 12,1 juta orang pada tahun 2015 atau 10,6 \% dari total tenaga kerja nasional. Pemerintah menargetkan jumlah wisatawan mancanegara yang mengunjungi Indonesia sebanyak 20 juta orang dan wisatawan nusantara sebanyak 275 juta orang pada tahun 2019 (Kementerian Pariwisata, 2017).

Undang-Undang Nomor 23 Tahun 2014 tentang Pemerintah Daerah mengamanatkan kewenangan khusus lembaga daerah yang dikenal dengan istilah otonomi daerah. Kewenangan ini memberikan keleluasaan bagi pemerintah daerah dalam mengurus sendiri urusan rumah tangganya untuk meningkatkan kesejahteraan masyarakat daerahnya, sesuai kemampuan dan potensi yang dimiliki. Implikasi dari berkembangnya konsep otonomi dalam pelaksanaan 
pembangunan daerah yaitu bahwa pemerintah daerah memiliki kewenangan untuk mengolah, memanfaatkan, dan mengelola setiap aset dan sumber daya daerah yang potensial untuk diberdayakan agar dapat memberikan konstribusi nyata bagi perkembangan daerah dan peningkatan taraf hidup masyarakat. Pemerintah daerah diarahkan agar mampu menentukan sektor-sektor strategis yang dapat mendorong terlaksananya pembangunan di daerah, salah satunya sektor pariwisata yang memiliki prospek yang bagus untuk dikembangkan.

Peluang pemanfaatan dan pengembangan sumber daya pariwisata menjadi tanggung jawab semua pihak terkait, khususnya lembaga pemerintahan daerah yang bertanggung jawab atas setiap aset dan sumber daya daerah diatur dalam Undang-Undang Nomor 10 Tahun 2009 tentang Kepariwisataan. Ketentuan perundang-undangan tersebut ditunjang dengan Peraturan Pemerintah Nomor 50 Tahun 2011 tentang Rencana Induk Pembangunan Kepariwisataan Nasional (RIPPARNAS) Tahun 2010-2025 yang selanjutnya menjadi pedoman bagi setiap daerah dalam merumuskan dan menyusun kebijakan pembangunan pariwisata sesuai karakteristik dan potensi daerah. Idealnya kebijakan pembangunan pada level daerah tidak hanya dijadikan sebagai bentuk ketaatan administratif lembaga daerah dalam pelaksanaan birokrasi pemerintahan tetapi juga merupakan bentuk pemahaman terhadap kebutuhan dan kapasitas daerah yang dituangkan melalui kebijakan pembangunan, sehingga kebijakan tersebut merupakan kebijakan yang dapat dilaksanakan dengan bertanggungjawab sesuai dengan prinsip-prinsip pembangunan.

Provinsi Jawa Tengah memiliki banyak potensi pariwisata salahsatunya adalah Dataran tinggi Dieng yang merupakan dataran tinggi yang tertinggi kedua di dunia setelah Nepal dan yang terluas di Pulau Jawa. Secara administratif Kawasan Dieng terbagi menjadi 2 kawasan yaitu Kawasan Dieng Kulon (Dieng Barat) yang terletak di wilayah Kabupaten Banjarnegara dan Kawasan Dieng Wetan (Dieng Timur) yang terletak di wilayah Kabupaten Wonosobo. Kawasan dataran tinggi Dieng merupakan sebuah kompleks gunung api terdiri dari Bisma, Seroja, Binem, Pangonan, Merdada, Pangerkandang, Telogo Dringo, Pakuwaja, Kendil, Kunir dan Prambanan. Kawasan Strategis Pariwisata Nasional (KSPN) Dieng dan sekitarnya merupakan kawasan atas dengan fungsi kawasan hutan, daerah resapan air, pertanian terbatas dan sebagainya. Kawasan ini memberikan perlindungan bagi kawasan di Kabupaten Wonosobo, Purbalingga, Temanggung dan sekitarnya. Atraksi wisata di KSPN Dieng dan sekitarnya terbagi menjadi 3 yaitu atraksi wisata alam, budaya, dan buatan. Atraksi wisata alam yang ada di Dieng umumnya berbentuk telaga dan mata air (telaga warna, pengilon, cebong dan menjer serta tuk bima lukar), kawah belerang (kawah Sikidang), dan gua (gua sumur, semar, dan jaran). Sedangkan atraksi wisata budaya di KSPN Dieng diantaranya hari jadi Kota Wonosobo, Tenong Suran, Tradisi Cukur Gembel, tari (jaran kepang, tari lengger, tari angguk) dan candi (Arjuna, Semar, Srikandi, Puntadewa, Sembadra, Gatutkaca, Bima dan Dwarawati). Adapun atraksi wisata buatan yaitu Dieng Plateu Theater, Gardu Pandang Tieng, Museum Purbakala, dan Agrowisata Tambi.

Jumlah wisatawan yang mengunjungi kawasan wisata Dieng di Kabupaten Banjarnegara terus mengalami peningkatan dari tahun 2013 sampai dengan 2017 hingga mencapai 266.705 orang. Peningkatan jumlah kunjungan wisatawan terbesar pada tahun 2014 yaitu 142.961 orang.Walaupun mengalami peningkatan jumlah wisatawan setiap tahun namun 
jumlah peningkatan tersebut terus menurun dibandingkan dengan tahun 2014. Pemerintah Kabupaten Banjarnegara juga mengadakan festival budaya guna mendongkrak jumlah wisatawan ke Dieng yaitu Dieng Culture Festival yang rutin diadakan setiap tahun.

Kawasan pariwisata Dieng yang terletak di 2 Kabupaten yaitu Kabupaten Banjarnegara dan Wonosobo serta daerahdaerah pendukungnya seperti Kabupaten Pekalongan, Batang, dan Kota Pekalongan membutuhkan suatu kerjasama antar daerah guna mendorong kemajuan dan pengembangan wisata di daerah Dieng. Oleh sebab itu, maka dibutuhkan kajian mengenai pentingnya kerjasama wisata antar pemerintah daerah, pemerintah pusat, dan juga pihak-pihak terkait guna meningkatkan kunjungan wisata ke Dieng.

Kawasan pariwisata Dieng merupakan kawasan wisata potensial di Jawa Tengah baik sumber daya alam, dan budayanya, namun menyimpan potensi konflik yang rentan. Sebagai suatu kawasan wisata yang potensial, keunikan Dieng tidak hanya karena adanya objek wisata yang beraneka ragam dalam satu kawasan, namun juga merupakan sebuah kawasan wisata yang terbagi menjadi dua wilayah administratif, yaitu Kabupaten Banjarnegara dan Kabupaten Wonosobo. Pengelolaan Kawasan Wisata Dieng yang baik akan sulit dilakukan tanpa adanya kerjasama antar daerah. Hasil penelitian Wahyudi (2010) menunjukkan bahwa KSPN Dieng sebagai kawasan wisata di berbatasan wilayah administrasi tidak terlepas dari gejala negatif adanya otonomi daerah dengan adanya ego dan sentimen kedaerahan. Untuk menghilangkan ego kedaerahan dicoba dengan menjalin kerja sama antara pihak-pihak yang berkepentingan pada kawasan wisata Dataran Tinggi Dieng. Kerjasama pengelolaan KSPN Dieng dan sekitarnya yang telah dilakukan oleh Kabupaten
Banjarnegara dan Kabupaten Wonosobo utamanya adalah kerjasama pengadaan tiket masuk terusan untuk kawasan wisata poros di Dieng, namun belum dilakukan kerjasama terintegrasi antar daerah dalam pengembangan dan pemberdayaan masyarakat pada KSP Dieng dan sekitarnya. Menurut Abdurrahman (2005) banyak kerjasama daerah maupun regionalisasi masih berhenti pada tataran MoU (surat kesepakatan bersama) atau masih kurang terasa manfaatnya.

Menurut data yang diperoleh dari Tim Fakultas Ekonomi Universitas Sanata Dharma Yogyakarta pada tahun 2018 mengenai Perumusan City Branding Kabupaten Wonosobo, dimana dilakukan penelitian mengenai persepsi wisatawan terhadap daerah tujuan wisata Wonosobo yang salahsatunya adalah kawasan wisata Dieng dengan menggunakan analisis pasar dan analisis SWOT. Hasil penelitian menunjukkan bahwa permasalahan pengembangan pariwisata kasawan Dieng adalah lama tinggal wisatawan di obyek wisata yang masih relatif singkat, atraksi wisata belum tergarap dengan baik dan aksesibilitas yang belum memenuhi syarat sebagai destinasi pariwisata nasional, masih banyaknya pungutan liar ke obyek wisata serta amenitas atau sarana penunjang pariwisata yang masih sangat terbatas.

Maksud penelitian ini adalah untuk mendukung terlaksananya kerjasama pengelolaan kawasan pariwisata Dieng secara terpadu dan terintegrasi, khususnya melalui rekomendasi strategi penguatan kerjasama kebijakan pembangunan pariwisata di KSPN Dieng dan sekitarnya.

Sedangkan tujuan penelitian yang akan diwujudkan yaitu:

1. Mengidentifikasi kondisi kerjasama daerah dalam hal pengelolaan KSPN Dieng dan sekitarnya di Kabupaten Banjarnegara, Wonosobo, Batang, Pekalongan dan Temanggung, 
2. Menganalisis faktor-faktor penghambat dan pendorong kerjasama daerah dalam pengelolaan dan pembangunan pariwisata serta

3. Merumuskan strategi penguatan kerjasama kebijakan pembangunan pariwisata di KSPN Dieng dan sekitarnya.

\section{METODE PENELITIAN}

Penelitian akan dilaksanakan di Jawa Tengah dengan mengambil lokasi di Kabupaten Banjarnegara, Kabupaten Wonosobo, Kabupaten Pekalongan dan Kabupaten Batang. Dasar pemilihan lokasi adalah kabupaten/kota yang merupakan kawasan pariwisata Dieng (Kabupaten Wonosobo dan Banjarnegara) dan daerah penyangganya (Kabupaten Batang dan Pekalongan). Penelitian dilaksanakan selama 8 (delapan) bulan, yaitu dimulai bulan Mei - Desember 2018.

Penelitian ini merupakan penelitian deskriptif kualitatif. Menurut Muhktar (2013) penelitian deskriptif kualitatif berusaha mendeskripsikan seluruh gejala atau keadaan yang ada, yaitu keadaan gejala menurut apa adanya pada saat penelitian dilakukan Metode kualitatif dilakukan karena permasalahan yang diangkat adalah permasalahan yang tidak terungkap melalui data-data statistik sehingga perlu pendekatan tertentu untuk memahaminya. Penelitian kualitatif merupakan cara untuk memahami perilaku sosial yang merupakan serangkaian kegiatan atau upaya menjaring informasi secara mendalam dari fenomena atau permasalahan yang ada didalam kehidupan suatu obyek dihubungkan dengan pemecahan suatu masalah baik dari sudut pandang teoritis maupun empiris. Sedangkan menurut Bogdan dan Taylor dalam Moleong (2002), metode kualitatif merupakan prosedur penelitian yang akan menghasilkan data kualitatif berupa kata- kata tertulis atau lisan dari orang-orang dan suatu proses yang diamati.

Subjek penelitian adalah para pemangku kepentingan pengembangan kawasan pariwisata Dieng baik pemerintah maupun non pemerintah. Informan penelitian adalah pihak yang memiliki kewenangan dalam perencanaan dan implementasi pengembangan kawasan pariwisata Dieng dari unsur pemerintah dan pelaku wisata (non pemerintah) serta aparat desa disekitar.

Data yang digunakan adalah data primer dan data sekunder. Data primer berasal dari wawancara dari para informan yang berisi tentang proses perencanaan, implementasi dan evaluasi kerjasama terpadu pengembangan kawasan wisata Dieng dan Focus Group Discussion (FGD). Sedangkan data sekunder berasal dari data dan dokumen-dokumen terkait pengembangan kawasan pariwisata Dieng.

Instrumen yang digunakan dalam penelitian ini adalah panduan wawancara atau daftar pertanyaan terbuka. Wawacara dengan informan tertentu secara mendalam terkait dengan obyek penelitian dan model kerjasama antar daerah tentang pariwisata. Instrumen lain adalah peralatan perekam data elektronik. Metode ini dilakukan agar data yang didapat lebih komprehensif.

Penelitian ini menggunakan teknik pengolahan dan analisis kualitatif model interaktif. Analisis model interaktif sebagaimana dikembangkan oleh Miles dan Hubberman (1984), dimana proses pengumpulan, pengolahan dan penyajian data secara simultan untuk menghasilkan kesimpulan yang saling terkait (Husaini dan Purnomo, 2008).

Pengolahan data dilakukan dengan model identifikasi kondisi eksisting, kemudian melakukan identifikasi perumusan faktor pendukung dan penghambat pengembangan kawasan wisata, membuat model dan strategi 
kerjasama antar daerah terkait pengelolaan pariwisata KSPN Dieng. Analisis data dilakukan melalui interaksi antara kondisi eksisting, faktor pendukung dan penghambat kerjasama antar daerah, strategi kerjasama antar daerah dalam pembangunan pariwisata khususnya KSPN Dieng.

\section{HASIL DAN PEMBAHASAN}

\section{A. Kondisi Kerjasama Daerah Dalam Hal Pengelolaan KSPN Dieng dan Sekitarnya}

Kerjasama antar daerah dalam hal pengelolaan KSPN Dieng sudah ada sejak tahun 1974 hingga tahun 2012. Pada tahun 1974 pihak yang terlibat adalah Bupati Wonosobo dengan Dinas Pariwisata Kabupaten Banjarnegara yang mengatur tentang pembinaan obyek-obyek wisata namun belum mengatur tentang adanya pembagian pendapatan yang diperoleh dari obyek-obyek wisata tersebut. Kesepakatan tersebut juga menetapkan Kabupaten Wonosobo sebagai pengelola.

Pemerintah Provinsi Jawa Tengah juga ikut berperan dalam pengelolaan KSPN Dieng dengan menetapkan Surat Keputusan Gubernur Jawa Tengah No. HK 14 Tahun 1997 tentang daerah kesatuan wisata dataran tinggi Dieng dengan pembagian wilayah masingmasing Kabupaten Banjarnegara (Desa Dieng Kulon, Desa Karangtengah, Desa Kepakisan, dan Desa Pekasiran) dan Wonosobo (Desa Dieng Wetan dan Desa Sembungan). Pada tahun 1978-1992 Pemerintah Kabupaten Banjarnegara dan Pemerintah Kabupaten Wonosobo kembali membuat kerjasama pengelolaan KSPN Dieng dengan penetapan lokasi di masingmasing kabupaten. Kerjasama tersebut juga memuat hal tentang pembagian pendapatan yang diperoleh yaitu sebesar 60\% untuk Pemerintah Kabupaten Banjarnegara sedangkan Pemerintah Kabupaten Wonosobo memperoleh $40 \%$ dan berhak menjadi pengelola KSPN Dieng.

Pada tahun 1992-1995, kerjasama antara Pemerintah Kabupaten Banjarnegara dengan Kabupaten Wonosobo diperluas dengan instansi dan lembaga yang terkait dengan kawasan wisata Dieng, diantaranya yaitu suaka peninggalan sejarah dan purbakala serta Perum Perhutani. Pemerintah Provinsi Jawa Tengah mendukung kerjasama antara Pemerintah Kabupaten Wonosobo dan Banjarnegara terkait dengan pengelolaan kawasan wisata Dieng, dan mengeluarkan surat keputusan Gubernur Jateng pada tanggal 23 November 1993 tentang kerjasama pengelolaan dan pengembangan obyek wisata dataran tinggi Dieng sehingga kemudian pada tahun 1994 ada keputusan koordinasi antara Kabupaten Banjarnegara dan Kabupaten Wonosobo yang dituangkan dalam program jangka pendek, menengah, dan jangka panjang.

Kemudian pada tahun 1995-1996, Bupati Banjarnegara dan Wonosobo sepakat untuk bekerjasama dengan menetapkan Surat Keputusan Bersama No. 04/1995 dan No. 20/1995 tentang kerjasama pengelolaan obyek wisata dataran tinggi Dieng. Kerjasama meliputi pengelolaan obyek wisata dan pembagian hasil pendapatan retribusi wisatawan, kendaraan wisata dan parkir. Selanjutnya pada tahun 1996-2000, kerjasama pengelolaan KSPN Dieng dituangkan dalam Surat Keputusan bersama antara Bupati Banjarnegara dan Bupati Wonosobo No. 43 dan No. 17 Tahun 1996 tentang Penetapan lokasi pemungutan Retribusi dan besarnya tarif retribusi wisatawan, kendaraan wisata dan parkir kendaraan wisata di obyek wisata Dieng.

Terkait dengan pengelolaan KSPN Dieng, muncul keberatan dari Dewan Perwakilan Rakyat Daerah (DPRD) Kabupaten Banjarnegara yang merasa bahwa kerjasama tahun 1995 dan 1996 
belum mencerminkan suatu keadilan sehingga muncul berbagai saran dan usulan dari masyarakat untuk meninjau kembali mengenai peraturan pembagian hasil pendapatan obyek wisata Dieng. Kemudian pada tahun 2002-2005, kerjasama pada periode ini tidak melibatkan Pemerintah Provinsi Jawa Tengah, namun hanya melibatkan Bupati Banjarnegara dan Bupati Wonosobo dengan membuat Surat Keputusan Bersama No.485 tahun 2002 dan No.17 Tahun 2002 tentang Kerjasama Pengelolaan dan Pengembangan Kawasan Dataran Tinggi Dieng pada tanggal 1 Agustus 2002. Bidang-bidang pokok yang dikerjasamakan antara lain: bidang pariwisata dan kebudayaan, bidang konservasi alam dan cagar budaya, pertanahan, pemberdayaan masyarakat, keamanan dan pendanaan serta membentuk forum kerjasama yang terdiri dari dewan penasehat (wakil bupati dan sekretaris daerah) dan pelaksana (instansiinstansi terkait di masing-masing kabupaten).

Pada tahun 2006-2008, kerjasama pada periode ini dilakukan oleh Pemerintah Provinsi Jawa Tengah, Pemerintah Kabupaten Banjarnegara dan Pemerintah Kabupaten Wonosobo dengan No. 556/2796, No. 050/582 dan No. 556/742/2006 tanggal 5 Oktober 2006 tentang Uji Coba Pelaksanaan Pungutan Karcis Masuk Terusan Kawasan Wisata Dataran Tinggi Dieng. Ruang lingkup dalam kerjasama ini mengenai obyek dan daya tarik wisata di kawasan poros, pengadaan karcis masuk terusan dilaksanakan oleh Pemerintah Provinsi Jawa Tengah, penentuan tarif karcis masuk terusan, pembagian hasil (proporsi $50 \%$ untuk Pemerintah Kabupaten Wonosobo dan 50\% untuk Pemerintah Kabupaten Banjarnegara), penentuan tempat dan pelaksanaan pungutan karcis masuk terusan.
Pada periode tahun 2008-2012 terbentuk kerjasama antara Pemerintah Provinsi Jawa Tengah, Pemerintah Kabupaten Banjarnegara, dan Pemerintah Kabupaten Wonosobo No. 050/1979, No.556/598.A, No.556/242/2008 tanggal 18 Juni 2008 tentang Pungutan Karcis Masuk Terusan Kawasan Dataran Tinggi Dieng. Adapun maksud dan tujuan serta ruang lingkup masih sama dengan perjanjian kerjasama uji coba pungutan karcis pada tahun 2006. Pemerintah Provinsi Jawa Tengah berkewajiban melaksanakan pembinaan dan pengawasan pelaksanaan karcis masuk terusan. Jangka waktu kerjasama ini berlaku selama 5 (lima) tahun sejak tanggal 1 Januari 2008 sampai dengan 31 Desember 2012.

Kemudian, pada tahun 2018 Pemerintah Provinsi Jawa Tengah, Menteri Pariwisata, Menteri Lingkungan Hidup dan Kehutanan, Menteri Pendidikan dan Kebudayaan, Menteri Tata Ruang dan Pertanahan, Direktur Utama Perum Perhutani, Bupati Banjarnegara, Bupati Wonosobo, Bupati Batang, dan Bupati Pekalongan akan menandatangani Kesepakatan Bersama (MoU) tentang pelestarian dan pengembangan Kawasan Strategis Pariwisata Nasional (KSPN) Dieng dan sekitarnya. Maksud kesepakatan bersama ini sebagai dasar untuk optimalisasi dan sinkronisasi kebijakan pelestarian dan pengembangan KSPN Dieng, sedangkan tujuannya adalah untuk mewujudkan pelestarian dan pengembangan dari aspek perlindungan cagar budaya, konservasi, pendidikan, kebudayaan, pariwisata dan pengembangan ekonomi masyarakat KSPN Dieng dan sekitarnya. Ruang lingkup MoU ini meliputi kegiatan:

1. Pelestarian, pengembangan, perlindungan dan konservasi sumberdaya alam, cagar budaya dan pariwisata,

2. Pengaturan kebijakan investasi dan perijinan, 
3. Penyediaan sarana dan prasarana,

4. Pengembangan pendidikan dan kebudayaan

5. Pemberdayaan masyarakat, dan

6. pembentukan lembaga pengelola

Semua biaya yang dapat timbul sebagai adanya kesepakatan kerjasama ini dibebankan pada APBN, APBD Provinsi Jawa Tengah, dan APBD kabupaten terkait. Jangka waktu kesepakatan ini berlaku selama 12 (dua belas) bulan dan dapat diperpanjang berdasarkan kesepakatan semua pihak. Diharapkan dengan adanya kesepakatan bersama ini mampu mendorong perkembangan KSPN Dieng dengan melibatkan daerah-daerah disekitarnya dan kementerian terkait sehingga tidak ada lagi kendala dan masalah dalam pengelolaannya. Sinergitas pemerintah pusat (kementerian terkait dan Perhutani) dan pemerintah daerah (provinsi dan kabupaten) serta keterlibatan masyarakat setempat perlu terus ditingkatkan guna mendukung peningkatan jumlah wisatawan KSPN Dieng. Surat kerjasama ini hendaknya dapat menjadi dasar pembentukan suatu lembaga/otorita pengelola KSPN Dieng dengan struktur organisasi yang melibatkan pihak-pihak terkait. Menurut Saputro (2011) terdapat 12 stakeholder dalam pengelolaan wisata di kawasan Dieng dan sekitarnya yaitu: Disparbud Kabupaten Wonosobo, Disparbud Kabupaten Banjarnegara, BKSDA Jawa Tengah, Paguyuban Pengemudi Dieng Batur, Perhimpunan Hotel dan Restoran Indonesia (PHRI), Kelompok Sadar Wisata "Dieng Pandawa", Dinas Kehutanan dan Perkebunan Kabupaten Wonosobo, Dinas Kehutanan dan Perkebunan Kabupaten Banjarnegara, Dinas Pertanian dan Tanaman Pangan Kabupaten Wonosobo, Dinas Pertanian dan Tanaman Pangan Kabupaten Banjarnegara, Tim Kerja Pemulihan Dieng (TKPD), dan Asosiasi Pedagang Carica (APC).
B. Faktor-faktor penghambat dan pendorong kerjasama daerah dalam pengelolaan dan pembangunan pariwisata

Baik disadari maupun tidak atau baik secara formal maupun tidak formal, bahwa antar wilayah kabupaten terjadi saling ketergantungan atau kerja sama yang saling menguntungkan antara kedua pihak. Ketergantungan atau kerja sama ini dapat terjadi karena masing-masing mempunyai keunggulan dan kekurangan masing-masing, sehingga terjadi saling mengisi antara keduanya. Faktor-faktor yang menjadikan adanya kerja sama antar daerah adalah adanya kepentingan bersama antar kedua belah pihak dalam mencapai suatu tujuan. Selain itu adanya hubungan saling membutuhkan atau prinsip supply and demand, karena keunggulan dan kekurangan masingmasing wilayah. Dengan tersedianya potensi unggulan yang dibutuhkan di wilayah lain merupakan faktor terjadinya kerja sama.

\section{Faktor-Faktor Penghambat Kerjasama Daerah dalam Pengelolaan dan Pembangunan Pariwisata}

Salahsatu faktor yang menghambat terjalinnya kerjasama baik kerjasama antar pihak maupun kerjasama antar daerah adalah belum/tidak adanya persamaan persepsi mengenai tujuan bersama yang ingin dicapai, dari hasil wawancara Kepala Dinas Pariwisata Kabupaten Wonosobo (One Andang Wardoyo) bahwa:

....konflik dalam pengelolaan KSPN Dieng adalah bagaimana menyatukan persepsi antara desa wisata dengan pokdarwis serta belum ada regulasi yang mendukung tentang pembentukan desa wisata dan kelompok sadar wisata... 
Kepala Sub Bidang Litbang Bappeda Kabupaten Wonosobo juga menuturkan bahwa:

...perlu ada pengelolaan konflik internal dan eksternal sehingga dibutuhkan formulasi kerjasama dalam pengelolaan Dieng...

Hal tersebut sesuai dengan hasil penelitian Sanctyeka (2009) bahwa faktor penghambat dalam kerjasama adalah adanya perbedaan kepentingan dan prioritas yaitu adanya perbedaan kepentingan antara desa wisata dengan kelompok sadar wisata yang berujung pada terjadinya konflik internal dan eksternal.

Selain itu, salahsatu faktor yang dapat menghambat kerjasama adalah lemahnya koordinasi antar sektor, berdasarkan hasil wawancara dengan Kepala Dinas Pariwisata Kabupaten Wonosobo (One Andang Wardoyo) bahwa:

...terkait dengan pengelolaan daerah wisata sekitar KSPN Dieng, pihak Perhutani hanya ingin bekerjasama dengan LMDH dan juga salahsatu contoh lainnya adalah kasus Menjer dimana PT Indonesia Power lebih cenderung bekerjasama dengan karang taruna...

\section{Pokdarwis Sembungan (Pak}

Burhanudin) juga menuturkan:

...belum ada standarisasi baik harga maupun kualitas homestay sehingga sering menimbulkan perang tarif dan kebingungan wisatawan, dan ada juga kasus biro travel Jawa Barat yang membawa tamu 15 orang di Telaga Menjer harganya dinaikkan...

Lemahnya koordinasi antar sektor dan antar daerah dalam hal pengelolaan pariwisata sebagai salahsatu penghambat kerjasama antar daerah sesuai dengan hasil penelitian Kuncoro (2004). Berdasarkan hasil wawancara juga dapat diketahui bahwa belum adanya regulasi kerjasama baik antar kabupaten maupun antara pemerintah pusat (Kementerian dan BUMN) dengan desa atau kelompok wisata atau payung hukum untuk pengelola wisata di desa. Hasil wawancara dengan PT Geo Dipa Energi (Bapak Agus) menyatakan bahwa:

..perlu ada aturan main atau regulasi yang jelas tentang pembagian pengelolaan Dieng secara jelas....

Bidang Litbang Bappeda Kabupaten Banjarnegara dan Pokdarwis Karang Tengah (Bapak Irhanto):

....perlu tindaklanjut dari provinsi terkait dengan kerjasama untuk Dieng sehingga bisa menjadi rujukan bagi perjanjian kerjasama-kerjasama lainnya....

Menurut Abdurrahman (2005) banyak kerjasama daerah maupun regionalisasi masih berhenti pada tataran MoU (surat kesepakatan bersama) atau masih kurang terasa manfaatnya. Hal ini antara lain disebabkan karena: masih minimnya kesiapan perangkat perundangundangan yang mendukung proses tersebut terutama yang melekat pada undang-undang pemerintahan daerah dan masih adanya kebiasaan strategi regionalisasi desentralistik yang sesuai dengan situasi serta kondisi di lapangan oleh para pelaku pembangunan. Sedangkan menurut Winarso (2002) permasalahan yang dapat diidentifikasi secara umum dari kerjasama daerah selama ini adalah belum tumbuhnya kesadaran akan pentingnya melakukan kerjasama oleh sebagian besar pemerintah daerah, dan jika kesadaran tersebut sudah muncul maka perlu ada mekanisme dan prosedur yang jelas, aplikatif dan tepat (proper) sebagai stimulannya. 
2. Faktor-Faktor Pendorong Kerjasama Daerah dalam Pengelolaan dan Pembangunan Pariwisata

a) Dukungan Stakeholder terhadap pengembangan KSPN Dieng

Dukungan perusahaan-perusahaan yang berada disekitar KSPN Dieng dan juga BUMN ikut berkontribusi terhadap pengembangan KSPN Dieng dalam bentuk program CSR. Salahsatu perusahaan yang ada di KSPN adalah PT Geo Dipa Energi dan Bank Indonesia yang membangun salahsatu infrastruktur pendukung yaitu toilet di Sebungan. Kementerian Lingkungan Hidup dan Kehutanan melalui BKSDA juga menganggarkan dana sebesar Rp. 1 Milyar untuk pembangunan sarana prasarana wisata alam (landmark, pondokan, jalan paving).

\section{b) Dukungan dana}

Terkait dengan pendanaan, baik pemerintah pusat, provinsi maupun daerah sudah menganggarkan setiap tahunnya. Kepala Dinas Pariwisata Kabupaten Wonosobo menuturkan:

....Pemerintah sudah menganggarkan dana sebesar 11 Milyar yang digunakan untuk pengembangan KSPN Dieng dan 2,3 Milyar dari Dana Alokasi Khusus (DAK) untuk Taman Syailendra...

Banyak dukungan dana baik dari pemerintah pusat Dana Alokasi Khusus (DAK), bantuan keuangan (Bankeu) dari pemerintah Provinsi Jawa Tengah

\section{c) Banyak event-event wisata bersama (Dieng Culture Festival), Festival Borobudur}

Event-event wisata tersebut diantaranya Dieng Culture Festival, Festival Borobudur, Borobudur Marathon, Festival Kota Lama, dsb diharapkan dapat meningkatkan jumlah kunjungan wisata- wan dengan tawaran paket wisata terintegrasi.

\section{C.Strategi Penguatan Kerjasama Kebijakan Pembangunan Pariwisata di KSPN Dieng dan Sekitarnya}

Menurut Rencana Induk dan

Rencana Detail KSPN Dieng dan sekitarnya Jawa Tengah (Dinbudpar Prov. Jateng, 2016) dalam pelaksanaan tata kelola kepariwisataan diperlukan kerjasama yang efisien dan efektif dari pemangku kepentingan baik pemerintah maupun pihak swasta. Berdasarkan UU RI No 10 Tahun 2009, ruang lingkup organisasi kepariwisataan meliputi:

1) Organisasi Pemerintah, Pemerintah Daerah, organisasi swasta dan organisasi masyarakat;

2) Regulasi dan Mekanisme Operasional di bidang kepariwisataan;

Pada KSPN Dieng dan sekitarnya membutuhkan tata kelola destinasi pariwisata yang terpadu dan bersinergi dengan menekankan pada pelestarian alam dan budaya, serta pelibatan para pihak yang berkepentingan dalam kegiatan pariwisata berdasarkan kemitraan dalam kesetaraan menuju pengembangan pariwisata berkelanjutan berbasis masyarakat. Tata kelola kawasan telah didukung antara lain oleh Organisasi Pemerintah Pusat, Pemerintah Daerah, swasta, dan masyarakat. Kondisi ini memerlukan satu bentuk kelembagaan khusus untuk pengelolaan KSPN Dieng ini. Kelembagaan ini dapat berbentuk 3 (tiga) lapis/ struktur. Struktur kelembagaan dimaksud antara lain adalah sebagai berikut: a) Struktur Pusat; yang berfungsi sebagai Badan Pengarah kebijakan yang memberikan arahan dan panduan Pengembangan, dan Pengelolaan; b) Struktur Provinsi dan Kabupaten/Kota; yang berfungsi sebagai Badan Koordinasi yang dipimpin langsung oleh Provinsi (dalam hal ini Gubernur); c) Struktur 
Pelaksana; yang berfungsi sebagai Badan Pelaksana atau eksekutor;

Pada struktur Pusat minimal terdapat 3 (tiga) Kementerian Koordinator (Kemaritiman dan Sumberdaya, Perekonomian, serta Pembangunan Manusia dan Kebudayaan) dan paling tidak 5 Kementerian terkait (Pekerjaan Umum dan Perumahan Rakyat, Perhubungan, Pertanahan Nasional dan Tata Ruang, Pendidikan dan Kebudayaan, Pariwisata). Sedangkan pada struktur provinsi dan kabupaten/kota sebagai Badan Koordinasi yang fungsi utamanya adalah sebagai Koordinator agar semua hal yang terkait dengan pemangku kepentingan dapat dikomunikasikan dan diakomodir secara optimal, sehingga pada bagian ini langsung dikoordinatori oleh Gubernur, karena sesuai dengan Undang-Undang 23 tahun 2014 tentang Pemerintahan, bahwa urusan lintas Kabupaten/Kota dilaksanakan oleh Provinsi. Namun hal ini lebih kepada koordinasi bermacam kepentingan yang ada. Pada struktur ini unsur yang terlibat paling sedikit yaitu:

a) unsur Kepariwisataan Kabupaten Banjarnegara yang langsung dikoordinir oleh Bupati (mengikutsertakan seluruh SKPD yang terkait dengan kepariwisataan sesuai dengan tugas dan Fungsi masing-masing),

b) unsur Kepariwisataan Kabupaten Wonosobo yang langsung dikoordinir oleh Bupati (mengikutsertakan seluruh SKPD yang terkait dengan kepariwisataan sesuai dengan tugas dan Fungsi masing-masing),

c) Unsur Asosiasi dan Industri Kepariwisataan (Kalangan Profesional), mencakup semua Asosiasi usaha dan Profesi di bidang Kepariwisataan, baik Tingkat Provinsi dan juga Kabupaten/Kota yang terkait.

Berdasarkan struktur kelembagaan di atas maka model kerjasama antar daerah dalam pengelolaan KSPN Dieng dan sekitarnya dapat ditunjukkan pada gambar di bawah ini.

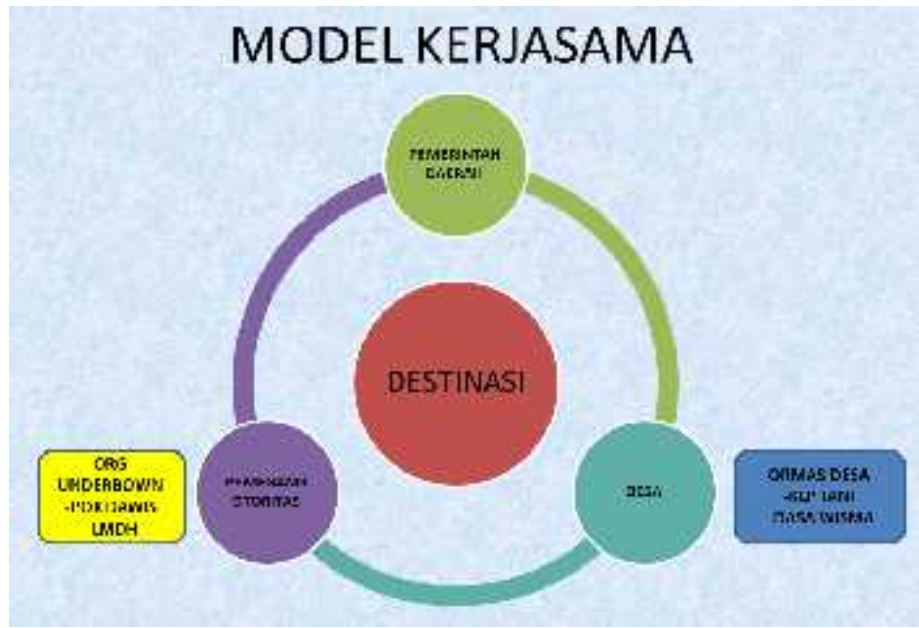

Sumber: Analisis Data, 2018

Gambar 5.1

Usulan Model Kerjasama

Model kerjasama antar daerah dalam pengelolaan destinasi wisata KSPN Dieng melibatkan pemerintah daerah (Kabupaten Banjarnegara dan Wonosobo serta Kabupaten Batang dan Pekalongan sebagai daerah penyangga), pemegang otoritas dalam hal ini adalah kelompok masyarakat sekitar yang terlibat 
didalamnya (pokdarwis, kelompok tani hutan, lembaga masyarakat desa hutan, dll) serta desa (ormas desa, gabungan kelompok tani, dasa wisma, BUMDes) agar dapat terjalin suatu sinergitas yang solid dalam pengelolaan KSPN Dieng.

Prospek atau peluang kerjasama pengelolaan KSPN Dieng dapat dilakukan oleh berbagai pihak diantaranya pemerintah daerah (Kabupaten Wonosobo, Kabupaten Banjarnegara, Kabupaten
Pekalongan, dan Batang), Pemerintah Provinsi Jawa Tengah, kementerian pusat (Pekerjaan Umum dan Perumahan Rakyat, Perhubungan, Pertanahan Nasional dan Tata Ruang, Pendidikan dan Kebudayaan, dan Pariwisata). Strategi akselerasi atau percepatan dalam hal kerjasama pengelolaan KSPN Dieng dalam 4 hal yaitu kelembagaan, pemasaran, destinasi, dan industri seperti yang terlihat pada gambar di bawah ini.

\section{STRATEGI AKSELERASI}

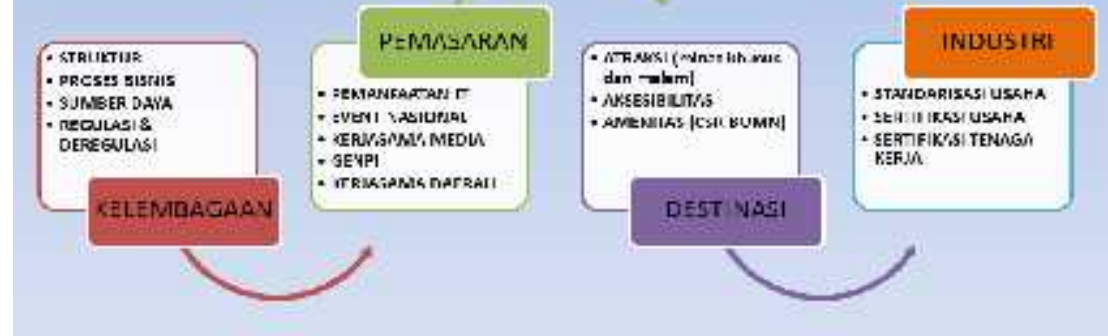

Sumber: Analisis Data, 2018

Gambar 5.2

Strategi Akselerasi Pengembangan KSPN Dieng

Dalam hal kelembagaan, dibutuh-

kan kejelasan mengenai strukturnya (pengarah, koordinator maupun pelaksana), proses bisnis yang akan dilaksanakan, sumberdaya yang akan digunakan (sumberdaya manusia, alam, teknologi) serta regulasi yang dapat menaunginya. Selain itu, pemasaran juga menjadi faktor yang sangat penting yaitu bagaimana memanfaatkan perkembangan teknologi informasi yang sudah semakin pesat (media sosial, elektronik, cetak, dll). Usaha kepariwisataan merupakan salah satu sektor yang secara terus menerus diupayakan pengembangannya agar dapat didayagunakan sebagai salah satu sektor andalan dalam kegiatan perekonomian daerah. Berkembangnya kegiatan pariwi- sata di suatu daerah akan memberikan pengaruh dan dorongan pembangunan sektor-sektor lainnya, khususnya dalam hal memperluas lapangan kerja dan peluang usaha. Menyadari bahwa sektor pariwisata merupakan salah satu sektor potensial yang mampu menjadi motor penggerak pembangunan daerah maka kegiatan pengembangan kepariwisataan merupakan salah satu prioritas yang mendapat perhatian dalam perencanaan pembangunan daerah Provinsi Jawa Tengah. Pemasaran dapat dilakukan melalui penyelenggaraan event nasional (visit Indonesia year, Dieng Cultural Festival, Festival Borobudur, visit Jawa Tengah), bekerjasama dengan media baik media cetak maupun elektronik serta 
media sosial, mewujudkan kerjasama antar daerah untuk mempromosikan KSPN Dieng.

Peningkatan kualitas destinasi baik dari sisi atraksi (minat khusus dan malam), penyediaan aksesibilitas menuju lokasi serta amenitas (bisa juga disediakan dari program CSR BUMN maupun perusahaan swasta) serta standarisasi usaha (homestay, kuliner, dll), sertifikasi tenaga kerja (pemandu wisata, pengelola homestay, dll), dan sertifikasi usaha (homestay, angkutan wisata, rumah makan/restoran, dll) guna menuju industri wisata yang diakui oleh dunia.

Dalam rangka untuk melaksanakan Peraturan Pemerintah Nomor 52 Tahun 2012 tentang Sertifikasi Kompetensi dan Sertifikasi Usaha di Bidang Parwisata ("PP 52/2012"), Menteri Pariwisata dan Ekonomi Kreatif menetapkan Peraturan Menteri Pariwisata dan Ekonomi Kreatif Nomor 1 Tahun 2014 tentang Penyelenggaraan Sertifikasi Usaha Pariwisata (Peraturan Menteri 1/2014). Berdasarkan Pasal 1 angka 2 Peraturan Menteri 1/2014, Sertifikasi usaha pariwisata adalah proses pemberian sertifikat kepada usaha pariwisata untuk mendukung peningkatan mutu produk pariwisata, pelayanan dan pengelolaan usaha pariwisata melalui audit. Peraturan Menteri 1/2014 mengatur lembaga sertifikasi usaha, tata cara sertifikasi, pengawasan sertifikasi usaha pariwisata, dan sanksi administratif oleh menteri. Lembaga Sertifikasi Usaha Bidang Pariwisata ("LSU Bidang Pariwisata") adalah lembaga mandiri yang berwenang melakukan seritifkasi usaha di bidang pariwisata sesuai dengan ketentuan peraturan perundang-undangan. Berdasarkan Pasal 14 ayat (1) UndangUndang Nomor 10 Tahun 2009 tentang Kepariwisataan ("Undang-Undang Kepariwisataan"), usaha pariwisata meliputi antara lain: a. daya tarik wisata; b. kawasan pariwisata; c. jasa transportasi wisata; d. jasa perjalanan wisata; e. jasa makanan dan minuman; f. penyediaan akomodasi; g. penyelenggaraan kegiatan hiburan dan rekreasi; h. penyelenggaraan pertemuan, perjalanan insentif, konferensi, dan pameran; i. jasa informasi pariwisata; j. jasa konsultan pariwisata; k. jasa pramuwisata; l. wisata tirta; dan $\mathrm{m}$. spa. Usaha pariwisata di KSPN Dieng dan sekitarnya belum memiliki sertifikasi usaha pariwisata yang diterbitkan oleh Lembaga Sertifikasi Usaha Bidang Pariwisata.

Terkait dengan strategi penguatan kerjasama kebijakan pembangunan pariwisata di KSPN Dieng, dalam dokumen Rencana Induk dan Rencana Detail KSPN Dieng dan sekitarnya Tahun 2016 disebutkan bahwa salahsatu misi Roadmap Pembangunan KSPN Dieng adalah mengembangkan kelembagaan dan sumberdaya pariwisata yang efektif, efisien dan professional dalam mewujudkan KSPN Dieng sebagai ecotourism yang berkualitas dan berkelanjutan dengan strategi harmonisasi kebijakan lintas sektoral dan lintas regional (dalam hal ini bisa diwujudkan dalam bentuk kerjasama antar daerah) dan pengendalian peraturan terkait ketertiban aktivitas kepariwisataan. Salahsatu programnya adalah pembentukan badan koordinasi lintas sektoral dan lintas regional terkait kepariwisataan KSPN Dieng dibawah kewenangan Pemerintah Provinsi Jawa Tengah sebagai koordinatornya.

\section{PENUTUP}

\section{Kesimpulan}

Kerjasama antar daerah dalam hal pengelolaan KSPN Dieng sudah ada sejak tahun 1974 hingga tahun 2012, namun kerjasama dilakukan secara parsial, yaitu antar 2 (dua) kabupaten atau kerjasama pemerintah provinsi dengan 1 (satu) kabupaten dalam sub sektor pariwisata 
tertentu. Pada tahun 2018 Pemerintah Provinsi Jawa Tengah, Menteri Pariwisata, Menteri Lingkungan Hidup dan Kehutanan, Menteri Pendidikan dan Kebudayaan, Menteri Tata Ruang dan Pertanahan, Direktur Utama Perum Perhutani, Bupati Banjarnegara, Bupati Wonosobo, Bupati Batang, dan Bupati Pekalongan telah menandatangani Kesepakatan Bersama (MoU) tentang pelestarian dan pengembangan Kawasan Strategis Pariwisata Nasional (KSPN) Dieng dan sekitarnya.

Adapun faktor-faktor penghambat kerjasama daerah dalam pengelolaan dan pembangunan pariwisata yaitu belum atau tidak adanya persamaan persepsi mengenai tujuan bersama yang ingin dicapai, lemahnya koordinasi antar sektor dan belum adanya regulasi kerjasama antar stakeholder. Sedangkan faktor-faktor pendorong kerjasama daerah dalam pengelolaan dan pembangunan pariwisata adalah terdapatnya dukungan stakeholder (perusahaan, kementerian, BUMN) terhadap pengembangan KSPN Dieng, adanya dukungan dana, serta banyak event wisata bersama seperti Dieng Culture Festival. KSPN Dieng dan sekitarnya memerlukan tata kelola destinasi pariwisata yang terpadu dan bersinergi dengan menekankan pada pelestarian alam dan budaya, serta pelibatan para pihak yang berkepentingan dalam kegiatan pariwisata berdasarkan kemitraan dalam kesetaraan menuju pengembangan pariwisata berkelanjutan berbasis masyarakat. Tata kelola kawasan telah didukung antara lain oleh Organisasi Pemerintah, Pemerintah Daerah, swasta, dan masyarakat. Kondisi ini memerlukan satu bentuk kelembagaan khusus untuk pengelolaan KSPN Dieng ini.

\section{Rekomendasi}

Diperlukan kerjasama terintegrasi antar pengampu kepentingan di tingkat pemerintah daerah kabupaten/kota, provinsi dan pemerintah pusat untuk mengakselerasi pembangunan pariwisata pada KSPN Dieng dan sekitarnya terutama setelah penandatangan MoU (Kesepakatan Bersama) antara Kementerian, Gubernur Jawa Tengah, Bupati Banjarnegara, Bupati Wonosobo, Bupati Batang dan Bupati Pekalongan. Strategi Akselerasi Pengembangan KSPN Dieng yang diusulkan adalah melalui: kelembagaan, pemasaran, destinasi, dan industri. 
DAFTAR PUSTAKA

A Abdurrahman, Benjamin. 2005. Pemahaman Dasar Regional Management dan Regional Marketing. Semarang: LEKAD

Furi, Hapsari Dyah Ratna. 2012. Penerapan Analisis SWOT pada Komponen Penawaran Pariwisata Taman Balekambang Surakarta. Skripsi. Surakarta: Fakultas Ekonomi Jurusan Ekonomi Pembangunan Universitas Negeri Sebelas Maret Surakarta

Kuncoro, Mudrajad. 2004. Otonomi dan Pembangunan Daerah, Reformasi, Perencanaan, Strategi dan Peluang. Jakarta: Erlangga

Wahyudi. 2010. Kajian Kerjasama Daerah dalam Pengelolaan dan Pengembangan Kawasan Wisata Dataran Tinggi Dieng. Tesis. Semarang: Program Studi Magister Teknik Pembangunan Wilayah dan Kota Universitas Diponegoro

Winarso,et.al. 2002. Pemikiran dan Praktek Perencanaan dalam Era Transformasi di Indonesia.
Bandung: Departemen Teknik Planologi ITB

Rencana Induk Pengembangan Pariwisata Jawa Tengah. 2004. Dinas Kebudayaan dan Pariwisata Provinsi Jawa Tengah

PT Sae Citra Endah. 2016. Rencana Induk dan Rencana Detail Kawasan Strategis Pariwisata Nasional (KSPN) Dieng dan Sekitarnya. Dinas Kebudayaan dan Pariwisata Provinsi Jawa Tengah

Saputro, Pramitama Bayu. 2011. Tata Kelola Wisata di Dataran Tinggi Dieng Provinsi Jawa Tengah. Bogor: Fakultas Kehutanan Institut Pertanian Bogor

Usman, Husaini \& Purnomo Setiady Akbar. 2008. Metodologi Penelitian Sosial. Bumi Aksara. Jakarta

Wahab, Salah. 2003. Manajemen Kepariwisataan. Jakarta: Pradnya Paramita

Yoeti, Oka A., 2008. Perencanaan dan Pengembangan Pariwisata. Jakarta: Pradnya Pariwisata 